
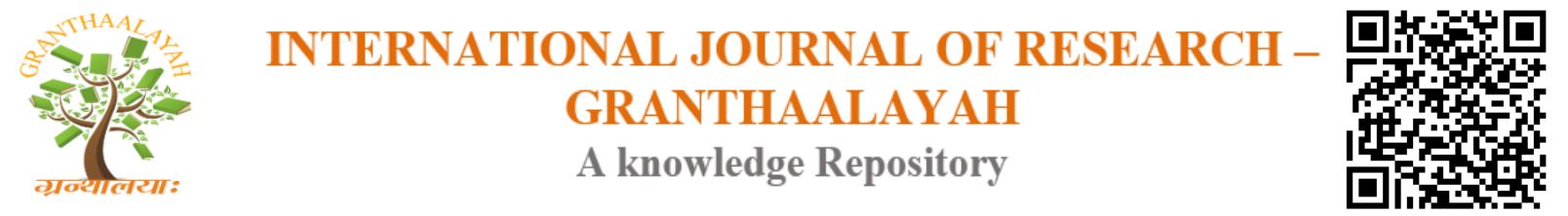

Social

\title{
PRACTICE RELATED TO OCCUPATIONAL HEALTH AND SAFETY AMONG WORKERS OF BRICK FACTORIES AT BHAKTAPUR, NEPAL
}

\author{
Krishna Bahadur G.C. ${ }^{1}$, Anoj Budhathoki ${ }^{2}$, Sushmita K.C. ${ }^{2}$, Kshitij Karki ${ }^{* 2}$ \\ ${ }^{1}$ Department of Community Medicine, Patan Academy of Health Sciences, Nepal \\ ${ }^{2}$ Department of Public Health, Asian College for Advance Studies, Nepal
}

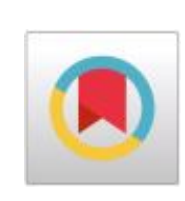

\begin{abstract}
The purpose of this study was to find out the practice related to occupational health and safety among the brick factory workers. The study was based on descriptive cross sectional design. Random proportionate sampling technique was applied to select the respondent from each randomly selected five brick factory. The total numbers of 300 samples of brick factory workers were selected. Semi-structured questionnaire and observation checklist were used for data collection. Most of the participants had knowledge about occupational health and safety. Similarly about $54.7 \%$ of them use gloves, $25.3 \%$ use boot and $18 \%$ use mask as personal protective equipment. Majority of participants were aware about occupational hazard but their practice level of personal protective equipment is low for protecting themselves. So the practice of personal protective equipment should be encouraged in the brick factory for the promotion of occupational health and safety.
\end{abstract}

Keywords: Personal Protective Equipment; Practice; Worker; Brick Factory.

Cite This Article: Krishna Bahadur G.C., Anoj Budhathoki, Sushmita K.C., and Kshitij Karki. (2018). "PRACTICE RELATED TO OCCUPATIONAL HEALTH AND SAFETY AMONG WORKERS OF BRICK FACTORIES AT BHAKTAPUR, NEPAL.” International Journal of Research - Granthaalayah, 6(3), 98-104. https://doi.org/10.29121/granthaalayah.v6.i3.2018.1503

\section{Introduction}

Workplace can pose threats to human health in some conditions. Occupational health is to maintain worker's health and working capacity, to improve the working environment to become conducive to safety and health, and to develop the working organizations and cultures in a direction which supports health and safety of people (Ahmed et. al., 2010) ${ }^{1}$. According to Society for Environment and Economic Development-Nepal (2013) successful occupational health and safety practice requires the collaboration and participation of both employers and workers in health and safety programs, and involves the consideration of issues relating to occupational medicine, industrial hygiene, toxicology, education, engineering safety, ergonomics, psychology, etc. ${ }^{2}$ 
Brick making is one of the main industrial activities in Nepal. There are around 429 brick kilns in operation in country. Fixed Chimney Bull's Trench Kiln (FBTK's) and Moving Chimney Bull's Trench Kiln (MBTK's) are the main technology used in Nepal. Almost all operational activities are based on manual works in the brick kilns. Brick making is one of the main industrial works in the Kathmandu valley. There are around 130 brick kilns in operation in the valley, with capacities up to 80 hundred thousand pieces of bricks per year, per kiln as per the Occupational Safety and Health Project $(2013)^{3}$.

Bhaktapur district is one of the main important economic as well as cultural centers of Kathmandu valley. In recent years, brick kilns have grown both in numbers and capacity due to increasing demand for construction materials for development work and urbanization, most brick kilns in the Kathmandu Valley functional from the month of December till May (Joshi \& Dudani) ${ }^{4}$.

According to Occupational Safety and Health Project (2013), identification and analysis of hazardous and risky work in brick industries hazards associated with the non-application of ergonomic principles, for example badly designed machinery, mechanical devices and tools used by workers, improper seating and workstation design, or poorly designed work practices. Most of the workers in Nepal face a combination of these hazards at work. For example, it is not difficult to imagine a workplace where one exposed to chemicals, unguarded and noisy machines, hot temperatures, slippery floors, etc. all at the same time ${ }^{3}$.

In Nepalese context, occupational health and safety are neglected and often given less attention. Negligence of occupational health and safety in day to day life is seen. Occupational safety and health is an important issue in this sector. It can prevent the workers from occupational diseases and accidents and same time increased the efficiency of workers. Most of processes involved in the brick production present hazards and risks possibly affecting workers' health. Especially, the dust of high free silica component could cause silicosis. Silicosis takes the highest percentage of occupational diseases in most countries, about 21 per cent to 54.6 per cent in developing countries. Heat stress is also main hazards for the brick kiln workers (Occupational Safety and Health Project, 2013) ${ }^{5}$. Lemon (2001) explained that flexibility in Occupational Health, Hygiene, and Safety at all work settings is essential in rapidly changing technologies and life ${ }^{6}$.

As per the Society for Environment and Economic Development-Nepal (2013), providing proper PPE could not help to mitigate the pollution from the kilns but it help workers to prevent the accumulation of toxicants that leads to chronic effects ${ }^{2}$. It is important to use PPE on hand, face and eye in the baking sections for preventing burns and visual impairment.

\subsection{Objective}

The overall objective of the study was to find out the practice related to occupational health and safety among the brick factory workers of Bhaktapur district in Nepal.

The main research question for the study was;

- What is the practice of occupational health and safety among workers? 


\subsection{Rational of Study}

There are certain works where workers are being exposed to extreme heat, cold, dust and smoke. Disease and injury from the exposure to extreme heat, cold, dust and smoke and bad working environment are the major problems of the brick factory workers. These incidents may even be greater than reported due to under reporting, lack of data and misdiagnosis. It also causes considerable damage to environment and local people living near by the brick factory.

It was expected to assess the use of Personal Protective Equipment (PPE) and its impact to the brick factory workers. It helps to prepare necessary guidelines for formulation of policies and implementation of intervention program for effective, thoughtful \& safer use of PPE. This could be another step to bring better working practices in brick factory so that disease and disabilities may not arise in person and community.

\section{Materials and Methods}

\subsection{Study Design}

A cross sectional descriptive study design was used. The study was conducted in Brick factory of Bhaktapur where many brick factories are available. The study variables were social factors, educational factors, training, institutional factors like availability of PPE, types of work, working duration, duration of exposure, use of PPE and drinking habits while working. Unbaked brick makers of brick factory of Bhaktapur district of Nepal were the target population. Primary source with quantitative data were collected by interview and observation using semi structured questionnaire and observation checklist respectively.

\subsection{Sampling Techniques and Sample Size}

The sample size for the study was 300 workers considering 50 percent prevalence and six percent error with addition of 10 percent non response rate. First of all, five randomly selected Brick factory of Bhaktapur were taken from total brick factories. Then, from each brick factory unbaked brick maker were selected randomly in a proportionate way i.e. 60 workers from each selected brick factory.

\subsection{Data Management}

Collected data were verified, coded as required and entered in Epi data. Analysis was done using the software SPSS. Frequency, mean and percentages were calculated from the data. The outcome of the study was interpreted by using tables.

Validity and reliability was maintained by reviewing the relevant literatures, adopting evidences, pre- testing and necessary modification of the questionnaires and checklist. 


\subsection{Ethical Considerations}

Ethical approval was taken from the research committee of Asian College for Advance Studies. Participants were informed about the objective, benefit and risks of participation in the study and verbal voluntary consent was obtained.

\section{Results and Discussions}

The study found that 35.3 percent of workers were at the age of 25-29 years and 66.7 percent were male. Concerning education, table 1 revealed that 36 percent participants were literate i.e. they can read and write their name properly and 64 percent were illiterate.

Table 1: Demographic characteristics of Particip
\begin{tabular}{|l|c|c|}
\hline Characteristics & Frequency & Percent \\
\hline Sex & & \\
\hline Male & 200 & 66.7 \\
\hline Female & 100 & 33.3 \\
\hline Education & & \\
\hline Literate & 108 & 36 \\
\hline Illiterate & 192 & 64 \\
\hline Smoking & & \\
\hline Yes & 241 & 80.3 \\
\hline No & 59 & 19.7 \\
\hline Alcohol & & \\
\hline Yes & 160 & 53.3 \\
\hline No & 140 & 46.7 \\
\hline
\end{tabular}

\subsection{Knowledge of Participant Workers on Problems}

Almost all participants were agreed that precaution should be adopted while working in brick factory and the use of PPE. Similarly, most of the brick factory workers had voiced cold and smoke emission from factory causes health problems and they were in need of training.

\subsection{Practice of Participant Workers on Occupational Health and Safety}

\subsubsection{Use of PPE}

The level of practice of PPE use was very low that is 86.3 percent among participant workers while only 2.3 percent of workers had high level of practice. It was found that the factory had not provided any types of personal protective equipment (PPE).

Table 2: Practice level of the Participants regarding the use of PPE

\begin{tabular}{|l|c|c|}
\hline Practice Level & Frequency & Percent \\
\hline Low & 259 & 86.3 \\
\hline Average & 34 & 11.3 \\
\hline High & 7 & 2.3 \\
\hline
\end{tabular}




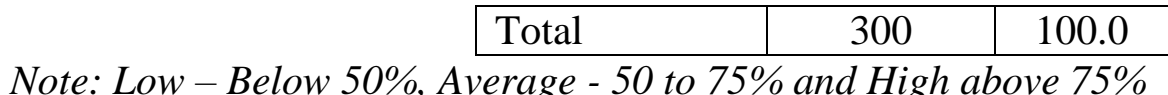

\subsection{Hygiene and Sanitation at Work Place}

Majority of the participants (68.7 percent) used well or tube well water and 31.3 percent used direct tap water for drinking purpose. Likewise, nearly half of the workers (48.3 percent) used toilet for defecation while 21.3 percent of them used to defecate in an open place.

\subsection{Health Service Utilization bye the Workers}

About two fifth of the workers (42.3 percent) had visited government health institution for treatment whereas 25.5 percent used to treat inside the factory. It was found that none of the workers used to keep First Aid Kit in the working place for emergency use.

Table 3: Health service utilization by brick factory workers

\begin{tabular}{|l|c|c|}
\hline Place & Frequency & Percent \\
\hline Private Institutions & 96 & 32 \\
\hline Government Institutions & 127 & 42.3 \\
\hline Inside Factory & 77 & 25.7 \\
\hline Total & 300 & 100 \\
\hline
\end{tabular}

\subsection{Education level and Use of PPE}

Among literate respondent only 2.78 percent had high level of practice of PPE whereas among illiterate 87.5 percent had low practice level.

Table 4: Association between education and practice of using PPE among participant workers

\begin{tabular}{|l|c|c|c|c|c|}
\hline \multirow{2}{*}{ Education Level } & \multicolumn{3}{|c|}{ Practice level n (\%) } & \multirow{2}{*}{ Chi- square } & P-value \\
\cline { 2 - 4 } & Low & Average & High & & \\
\hline Literate & $91(84.26)$ & $14(12.96)$ & $3(2.78)$ & 0.62 & 0.73 \\
\hline Illiterate & $168(87.50)$ & $20(10.42)$ & $4(2.08)$ & & \\
\hline
\end{tabular}

\subsection{Discussions}

The study showed that most of the participants had heard about occupational health and safety. More than half (54.7 percent) of them use gloves, 25.3 percent use boot and 18 percent use mask as PPE. Education level was not related to use of PPE in present study while a study conducted in eastern Nepal (Budhathoki et. al., 2014) on occupational hazards and safety had had a significant relationship education level and the use of PPE $(\mathrm{p}<0.05)^{7}$.

It was found that about half of the participants used to work 8-10 hours daily and about 42 percent of them used to work 11-13 hours daily while ILO has given the standard working hour for every worker should not exceed 8 hours daily. However, another study in Pakistan by Zia-urRahman et. al., found that brick factory workers work for $12-14$ hours without any overtime ${ }^{8}$. 
This study revealed that about 21 percent of the workers were open defecating. Whereas, in another study by DMC-Nepal (2003), only three percent worker families have toilets and nearly 14.29 percent children used the toilets ${ }^{9}$.

Despite much strength, the study has many limitations such as inclusion of limited types of participants (mainly seasonal workers) and not generalizable to other occupations.

\section{Conclusions and Recommendations}

Most of the participants did not use any type of PPE. More than two fifth of the participants had utilized health services from government health institution. Over work load and unhealthy working environment are the major causes of the occupational health hazards. Majority of participants were aware about occupational hazard but their PPE practice level is low. So, the practice of PPE should be encouraged in the brick factory for the promotion of occupational of health and safety. Although Nepal Government has declared Bhaktapur district as Open defecation free district, still 21.3 percent of the workers used to defecate openly. The concern authorities should take immediate action against it.

\section{Acknowledgements}

The credit of this study conduction goes to all those who helped me from their respective sides. We would like to thanks Asian College for Advance Studies for providing us with this opportunity to conduct a research. Our special thanks goes to manager of all the brick factories who helped us to conduct our study in their respective factory. We would like to express our gratitude and ask for forgiveness for those who are not being cited.

\section{References}

[1] Ahmed HO, S Mark and S Newson. (2010). KNOWLEDGE AND PRACTICES RELATED TO OCCUPATIONAL HAZARDS AMONG CEMENT WORKERS IN UNITED ARAB EMIRATES. J Egypt Public Health Association, 85 (3-4), 149-67.

[2] Society for Environment and Economic Development-Nepal. (2013). IDENTIFICATION AND ANALYSIS OF HAZARDOUS AND RISKY WORKS IN BRICK MANUFACTURING INDUSTRIES OF NEPAL. Kathmandu, Nepal: Society for Environment and Economic Development-Nepal.

[3] Occupational Safety and Health Project. (2013). IDENTIFICATION AND ANALYSIS OF HAZARDOUS AND RISKY WORKS IN BRICK MANUFACTURING INDUSTRIES OF NEPAL. Kathmandu, Nepal: Project, Occupational Safety and Health.

[4] Joshi , S. K., \& Dudani, I. (2008). ENVIRONMENTAL HEALTH EFFECTS OF BRICK KILNS IN KATHMANDU VALLEY. Kathmandu University Medical Journal, 3.

[5] Occupational Safety and Health Project. (2013). OCCUPATIONAL SAFETY AND HEALTH IS AN IMPORTANT ISSUE IN THIS SECTOR. Kathmandu, Nepal: Occupational Safety and Health Project.

[6] Lemon, T.B. (2001). THE FUTURE OF OCCUPATIONAL SAFETY AND HEALTH. International Journal of Occupational Safety and Ergonomics, 7(4), pp. 403-408.

[7] Budhathoki SS, Singh SB, Sagtani RA, Niraula SR \& Pokhrel PK. (2014). AWARENESS OF OCCUPATIONAL HAZARDS AND USE OF SAFETY MEASURES AMONG WELDERS: A CROSS-SECTIONAL STUDY FROM EASTERN NEPAL. BMJ Open; 4:e004646. 
[8] Zia-ur-Rahman, Noshi , A., Khan , T., \& Dr. A. (2012). STATUS OF OCCUPATIONAL HEALTH AND SAFETY IN BRICK KILN INDUSTRIES AT HATTER INDUSTRIAL ESTATE HARIPUR. Journal of Environment, 56.

[9] Development Management Support Centre (DMC-Nepal). (2003). SITUATIONAL ANALYSIS OF WORKERS IN SOME BRICK INDUSTRIES AROUND KATHMANDU VALLEY, Kathmandu, Nepal: Development Management Support Centre (DMC-Nepal).

*Corresponding author.

E-mail address: kshitijkarki@ yahoo.com 